\title{
TYPES OF CAMPSITES IN CROATIAN TOURISM SUPPLY - A CASE STUDY OF THE TOWN OF KRK
}

\author{
Vid Doric ${ }^{40}$ \\ Vuk Tvrtko Opačic ${ }^{41}$
}

\begin{abstract}
The paper presents the main features of camping tourism in Croatia through the stages of its development, as well as its significance in recent Croatian tourism supply. The goal of the research is to contribute to the development of the campsites' typology in contemporary tourism supply of Croatian coastal tourism destinations, based on differences in the capacity of campings, location factors, spatial impacts and the consequences, characteristics of supply in campings as well as motivations, attitudes and habits of camping tourists in each of the types of campsites.

Krk, the largest settlement on the island of Krk, was chosen as a representative case study. Krk is a tourism destination with traditionally developed camping tourism. Campsites, as a type of accommodation capacities that occupy the largest areas in the town, have had a significant impact on its spatial and economic development, primarily through changing the usage and the value of land, socioeconomic and socio-cultural transformation of the local population, changes in the structure of tourism supply and environmental implications. In the example of the town of Krk, three types of campsites are identified: a) traditional camping, b) exclusive camping, and c) small family run camping. This typology can be applied on a wider scale Croatian level.

In addition to literature overview, quantitative tourism statistic data interpretation and continuous field research, direct questionnaire survey in July 2016 was conducted. A nonprobabilistic occasional sample included a total of 127 camping tourists in Camping Ježevac (example of a traditional camping), Camping Resort Krk (example of an exclusive camping) and Camping Bor (example of a small family run camping). In order to identify differences in the motivation, attitudes and habits of respondents in different types of campings, the results of the survey are processed using standard descriptive statistics methods.
\end{abstract}

Key words: camping tourism, typology of campsites, traditional camping, exclusive camping, small family run camping, Krk, Croatia

\section{INTRODUCTION}

Although the first campsites along the Croatian coast were founded before the Second World War, mainly in the Northern Croatian Littoral, most of them were opened on the coast and on the islands in the second half of the $20^{\text {th }}$ century in the period of socialist Yugoslavia. According to Cvelić-Bonifačić (2003), in the development of camping tourism in Croatia five stages can be distinguished: a) beginnings of camping (from the

\footnotetext{
${ }^{40}$ MS, Svetog Mateja 51, 10000 Zagreb, Croatia.

${ }^{41}$ Associate Professor, University of Zagreb, Faculty of Science, Department of Geography, Marulićev trg 19/II, 10000 Zagreb, Croatia.
} 
end of the Second World War to the end of the 1960s), b) intense growth of camping (from the late 1960s to the end 1970s), c) the peak of camping tourism (in 1980s), d) crisis in camping tourism caused by the Croatian Homeland War (in the beginning of 1990s), and e) the recovery of camping tourism with the implementation of new supply. The development of camping tourism in Croatia during the period of socialism was based on traditional camping, while the concept of modern ("high-tech") camping appears in the stage of recovery of camping tourism after the end of the Croatian Homeland War (1995) with its high volume in the last 15 years (Hendija, 2006) (Fig. $1)$.

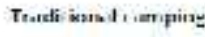

$19=0$ 19าง

$\rightarrow$ eresp hol days

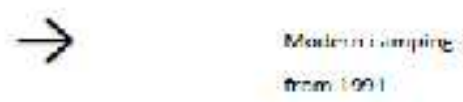

Campine characteristics

$\rightarrow$ expensive (el te) hol days

> "hotrl industry an open spher'

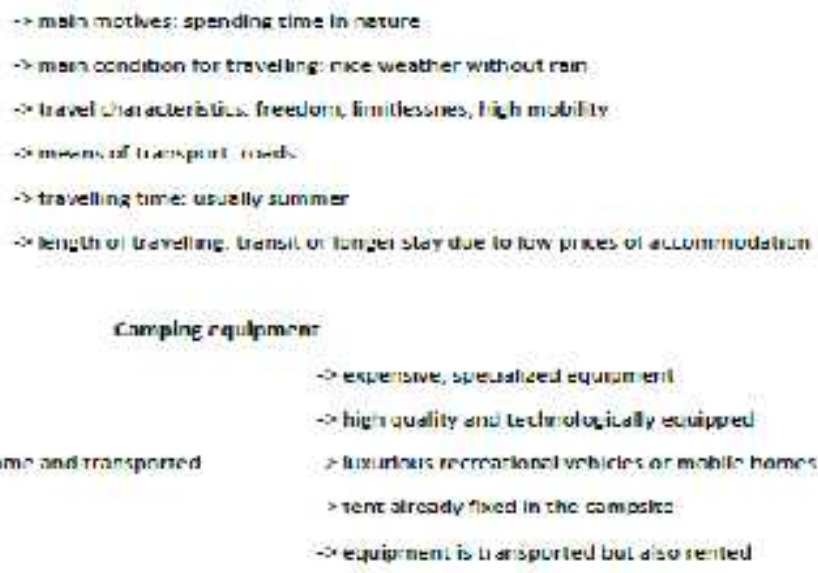

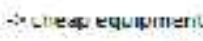

- itul, cart p lade!

> all rquipmerr hat ger ar homo vas transpnned

requig nent is hat spurled bul dise senled

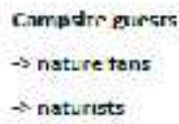

$\rightarrow$ masspe: all tounsts of lower incame

$\rightarrow$ midde ages and youns people

-> dehned market segments: hagt income, sco triendly, kw inturem jainda

\section{Compdte bchovlour}

$\rightarrow$ eco trienclv austs, respectul to the nature

$>$ arcent to rine eartallminn

> snrlal ging hid with repert of the prlwary

> assive hollosyz, butring, roing we the beach

> active hollsave with partidipadion in eltferent sctidtic: and pregra me in destination

Fig. 1. Comparison between traditional and contemporary way of camping Source: Hendija, 2006 
In the initial developmental stage of Croatian camping tourism, investment in building campsites was one of the most cost-effective tourism investments. For their openings it was necessary only to provide the attractive plot of land near the sea and initial capital for the investment in basic, relatively modest infrastructure. In that time there was more than enough suitable land for converting into the campsites, because of emigration of local inhabitants that occurred in many parts of Croatian littoral and on the islands. Due to the modest infrastructure, Croatian campsites were less competitive compared to campsites in other Mediterranean countries. During the period of socialism, Croatian campings were often part of larger socially-owned tourism companies, and the realized profit was generally used to moderate the deficit of other segments of the company, i.e. in hotels and tourist resorts, in case of losses. Such management policy has resulted in low investments in upgrading infrastructure as well as tourism supply in campings. Naturist campings were one of the specialties of the Croatian camping supply (Camping Koversada, near Vrsar in Istria, was the first naturist camping in Europe - opened in 1961). Consequently, Croatia has become one of the most popular naturist destinations in Europe (Sladoljev, 2001; Smolčić Jurdana et al., 2009).

The absolute peak of Croatian camping tourism was achieved in 1986 when 18 million tourist nights were realized and the capacities of campsites were full for more than two months (64.5 days) (Sladoljev, 1998). Since the simple camping tourism supply based on "Sun and Sea" concept was no longer interesting for tourists from the emissive tourism markets of Western and Central Europe, a slow stagnation of Croatian camping tourism began, followed by a sudden fall caused by the Croatian Homeland War.

In the last two decades, especially in the last few years, both increase of the tourism flow in campings and upgrading quality and camping supply appears. In 2016, there were 2,544,000 tourist arrivals and 17,084,000 tourist nights recorded in all Croatian campings (Croatian Bureau of Statistics, 2017). Campsites, campsites in households and campsites in rural households are the third most visited type of tourist accommodation facilities in the Republic of Croatia (Fig. 2). Foreign camping tourists prevail in the structure of camping tourist arrivals in 2016 (97.33\% of all tourist arrivals in Croatian campsites were realized by foreign tourists), mostly from Germany (27.88\%), Slovenia (19.53\%), Italy (9.94\%), Austria (9.54\%) and the Netherlands (7.60\%) (Croatian Bureau of Statistics, 2017). 


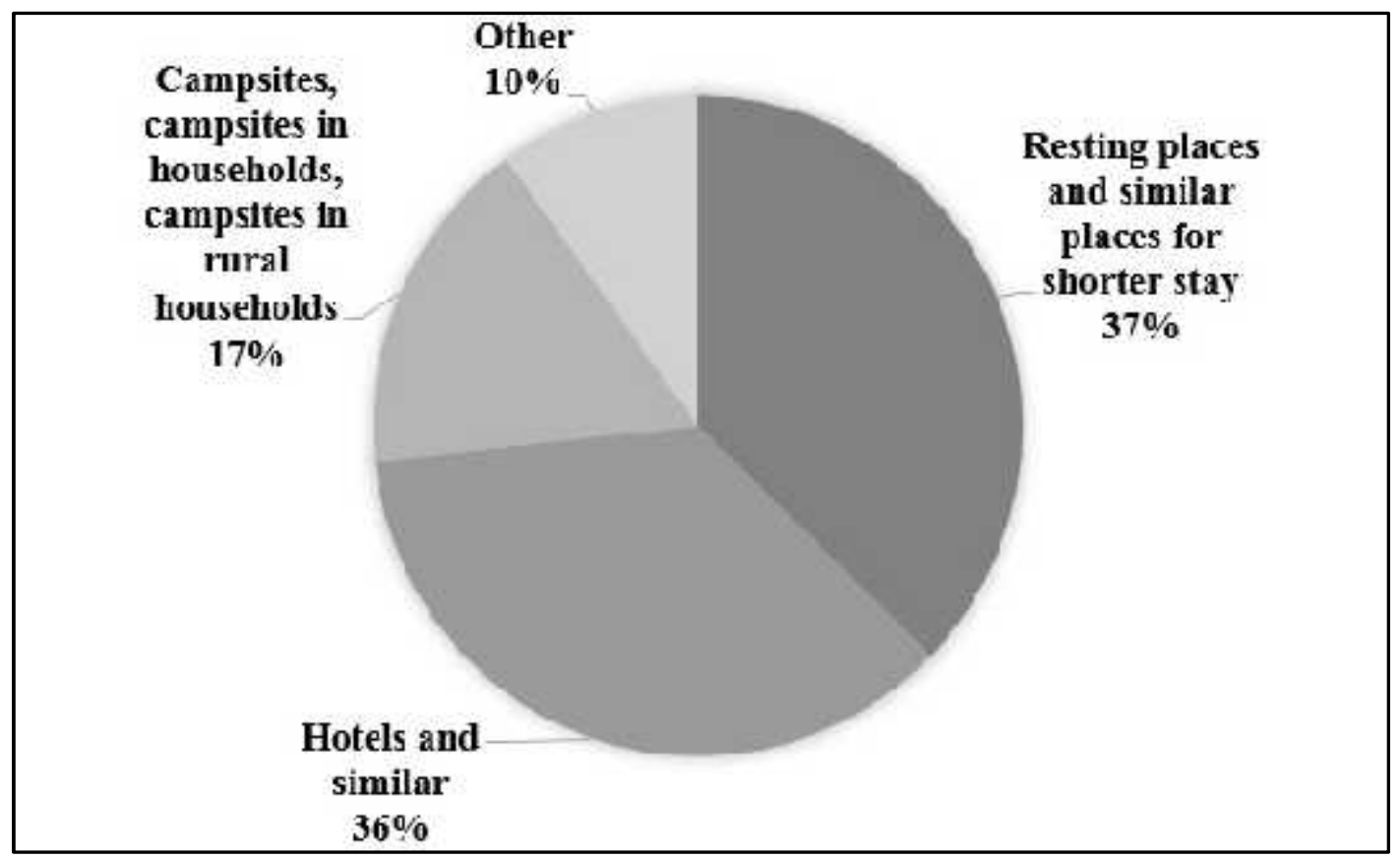

Fig. 2. Arrivals of tourists in Croatia in 2016 by accommodation type

Source: Croatian Bureau of Statistics, 2017

The favorable tourism-geographical position and the proximity of emissive tourist regions is the main reason for the spatial distribution of camping capacities in Croatia. Thus, the convincingly largest number of campsites and campsites pitches is recorded in Istria and Primorje-Gorski Kotar County (Seleši, 2010) (Fig. 3). 


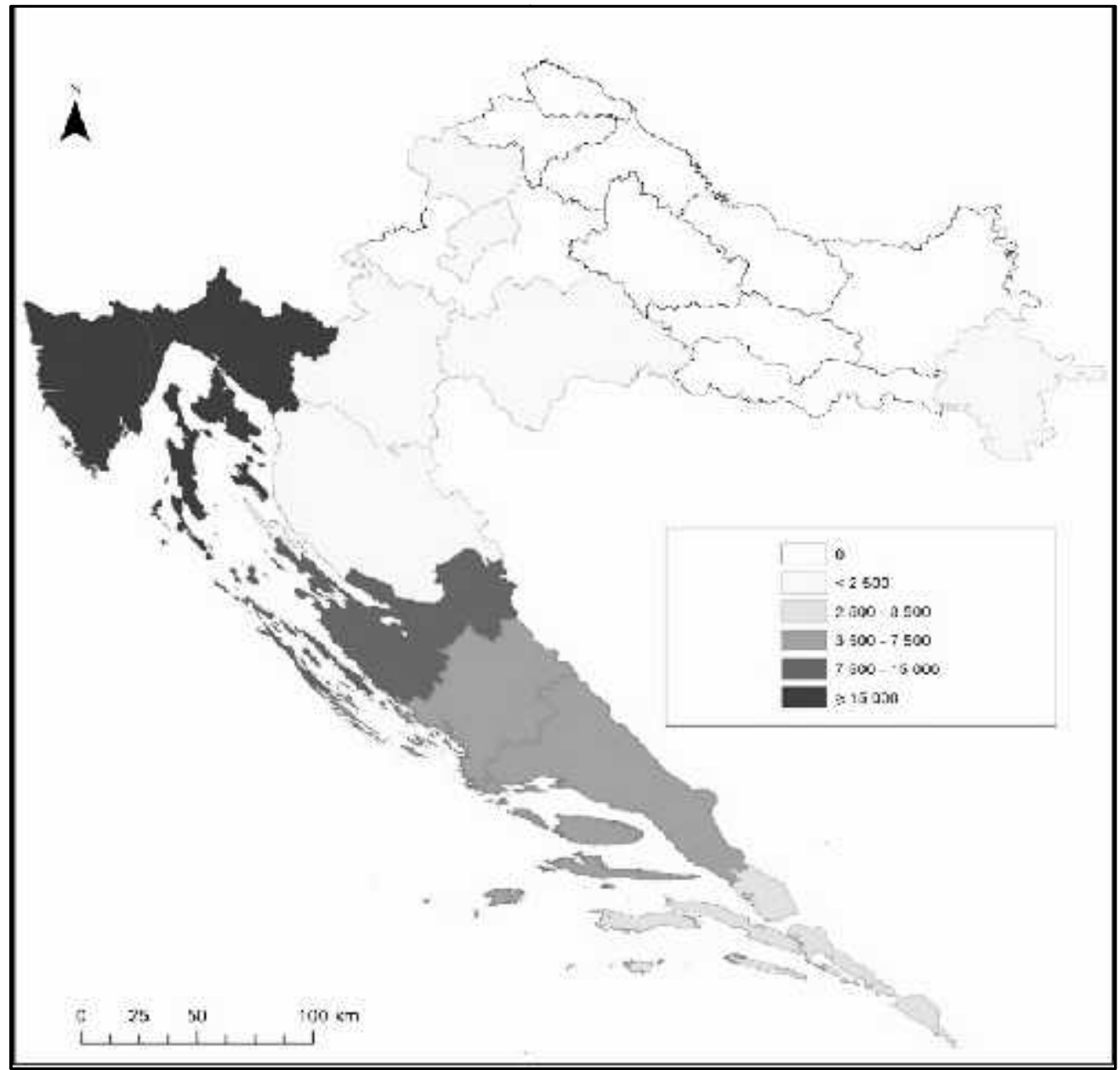

Fig. 3. Number of campsite pitches in Croatia in 2013

Sources: Croatian Bureau of Statistics, 2014; State Geodetic Administration, 2005

Same as in more developed European tourism countries, in Croatia the concept of camping tourism is changing. Modern ("high-tech") camping is slowly strengthening, while the share of traditional camping is decreasing at the same time. Camping equipment is becoming more sophisticated, camping supply more diverse and expensive, and the degree of built areas in campsites, as well as share of built, i.e. fixed, buildings in campsites (apartments, mobile homes, tents for glamping) is increasing. Raising the quality of the supply also affects the camping tourist profile change. Along with camping tourists who are accustomed to camping (most of them prefer camping from their childhood) and camping tourists of lower financial ability, camping tourism becomes increasingly attractive to camping tourists of higher incomes, resulting in higher profits. 
In order to optimize the future development of camping tourism in Croatia, it is necessary to identify the types of campsites in its recent tourism supply, which is the main goal of this research.

\section{RESEARCH GOAL AND METHODOLOGY}

The goal of the research is to contribute to the development of the campsites' typology in contemporary tourism supply of Croatian coastal tourism destinations, based on differences in the capacity of campsites, location factors, spatial impacts and the consequences, characteristics of supply in campsites as well as motivations, attitudes and habits of camping tourists in each of the types of campsites. In the example of the town of Krk, the largest settlement on the island of Krk, three types of campsites in the contemporary tourism supply in Croatia, are identified: a) traditional camping, b) exclusive camping, and c) small family run camping.

In addition to literature overview, quantitative tourism statistic data interpretation and continuous field research, direct questionnaire survey in July 2016 was conducted. A nonprobabilistic occasional sample included a total of 127 camping tourists in Camping Ježevac (example of a traditional camping), Camping Resort Krk (example of an exclusive camping) and Camping Bor (example of a small family run camping) (Tab. 1). In order to identify differences in the motivation, attitudes and habits of respondents in different types of campings, the results of the survey are processed using standard descriptive statistics methods.

Tab. 1. Socio-demographic characteristics of the respondents in three types of campsites in the town of Krk

\begin{tabular}{|c|c|c|c|c|c|c|}
\hline & \multicolumn{2}{|c|}{$\begin{array}{c}\text { BOR } \\
\text { (small family run } \\
\text { camping) } \\
(\mathrm{N}=36)\end{array}$} & \multicolumn{2}{|c|}{$\begin{array}{l}\text { JEŽEVAC } \\
\text { (traditional } \\
\text { camping) } \\
(\mathrm{N}=62)\end{array}$} & \multicolumn{2}{|c|}{$\begin{array}{c}\text { CAMPING } \\
\text { RESORT KRK } \\
\text { (exclusive camping) } \\
(\mathrm{N}=29)\end{array}$} \\
\hline Gender & $\mathrm{F}=20$ & $M=16$ & $\mathrm{~F}=32$ & $\mathrm{M}=30$ & $F=19$ & $M=10$ \\
\hline $\begin{array}{l}\text { Average } \\
\text { age }\end{array}$ & \multicolumn{2}{|c|}{43.42} & \multicolumn{2}{|c|}{42.80} & \multicolumn{2}{|c|}{39.41} \\
\hline \multirow{3}{*}{$\begin{array}{l}\text { Level of } \\
\text { education }\end{array}$} & $\begin{array}{l}\text { Elementary } \\
\text { school }\end{array}$ & 2 & $\begin{array}{l}\text { Elementary } \\
\text { school }\end{array}$ & 4 & $\begin{array}{l}\text { Elementary } \\
\text { school }\end{array}$ & 1 \\
\hline & High school & 5 & High school & 24 & $\begin{array}{l}\text { High } \\
\text { school }\end{array}$ & 6 \\
\hline & $\begin{array}{l}\text { College, } \\
\text { university } \\
\text { and higher }\end{array}$ & 25 & $\begin{array}{l}\text { College, } \\
\text { university } \\
\text { and higher }\end{array}$ & 31 & $\begin{array}{l}\text { College, } \\
\text { university } \\
\text { and higher }\end{array}$ & 21 \\
\hline
\end{tabular}




\begin{tabular}{|l|l|r|l|r|l|r|}
\hline & Unknown & 4 & Unknown & 3 & Unknown & 1 \\
\hline \multirow{5}{*}{ Nationality } & Slovenia & 4 & Slovenia & 23 & Slovenia & 3 \\
\cline { 2 - 6 } & Germany & 10 & Germany & 11 & Germany & 10 \\
\cline { 2 - 6 } & Netherlands & 10 & Netherlands & 2 & Netherlands & 14 \\
\cline { 2 - 6 } & Croatia & 0 & Croatia & 13 & Croatia & 0 \\
\cline { 2 - 6 } & Switzerland & 0 & Switzerland & 3 & Switzerland & 1 \\
\cline { 2 - 6 } & Austria & 2 & Austria & 1 & Austria & 1 \\
\cline { 2 - 6 } & Other & 10 & Other & 9 & Other & 0 \\
\hline
\end{tabular}

\section{CAMPSITES IN THE TOWN OF KRK}

The town of Krk stands out among the other towns/municipalities on the island by the number of campsites. In the town area there are 3 campsites: Camping Bor (3-star category), Camping Ježevac (4 stars), and Camping Resort Krk (5 stars since the 2016 tourist season) (Town of Krk Tourist Board, 2017). Same as in other coastal and island Croatian tourism destinations, in the second half of the $20^{\text {th }}$ century, in the town of Krk mass tourism has been developed, and for this purpose a socially-owned tourism company "Hotelsko poduzeće Krk", later renamed in "OOUR Zlatni otok" was established. Within the company several hotels and 2 camps were opened: Camping Ježevac (in 1961) and naturist Camping Politin (1986), today Camping Resort Krk (Zlatni otok hotelijerstvo, turizam, trgovina, 2017). Camping Bor, opened in 1985 as the third campsite in town, was the first private camping in socialist Yugoslavia (Independent Internet Site of the Island of Krk, 2015).

As it is usually the case, campsites in the town of Krk are located on the edge of the town, away from the center. Unlike campings Ježevac and Politin, which were built on the coast, Camping Bor is situated in the inner part of the town, away from the coast, on the former olive grove on private land. There were plans for building hotels on the locations of campings Ježevac and Politin, but this did not happen due to the lack of funds. The intensive apartmentalization in the town of Krk has led to the fact that the campings Ježevac and Bor are no longer separate from the town. Contrary, naturist Camping Politin, which became the conventional Camping Resort Krk in 2013, is still situated away from the built area of town. According to the Spatial Plan of the Town of Krk (2007a), land intended for the expansion of tourism activities is mostly located in the eastern parts of the settlement (along Camping Resort Krk) and, somewhat in the southern parts along the Camping Ježevac (Fig. 4). 


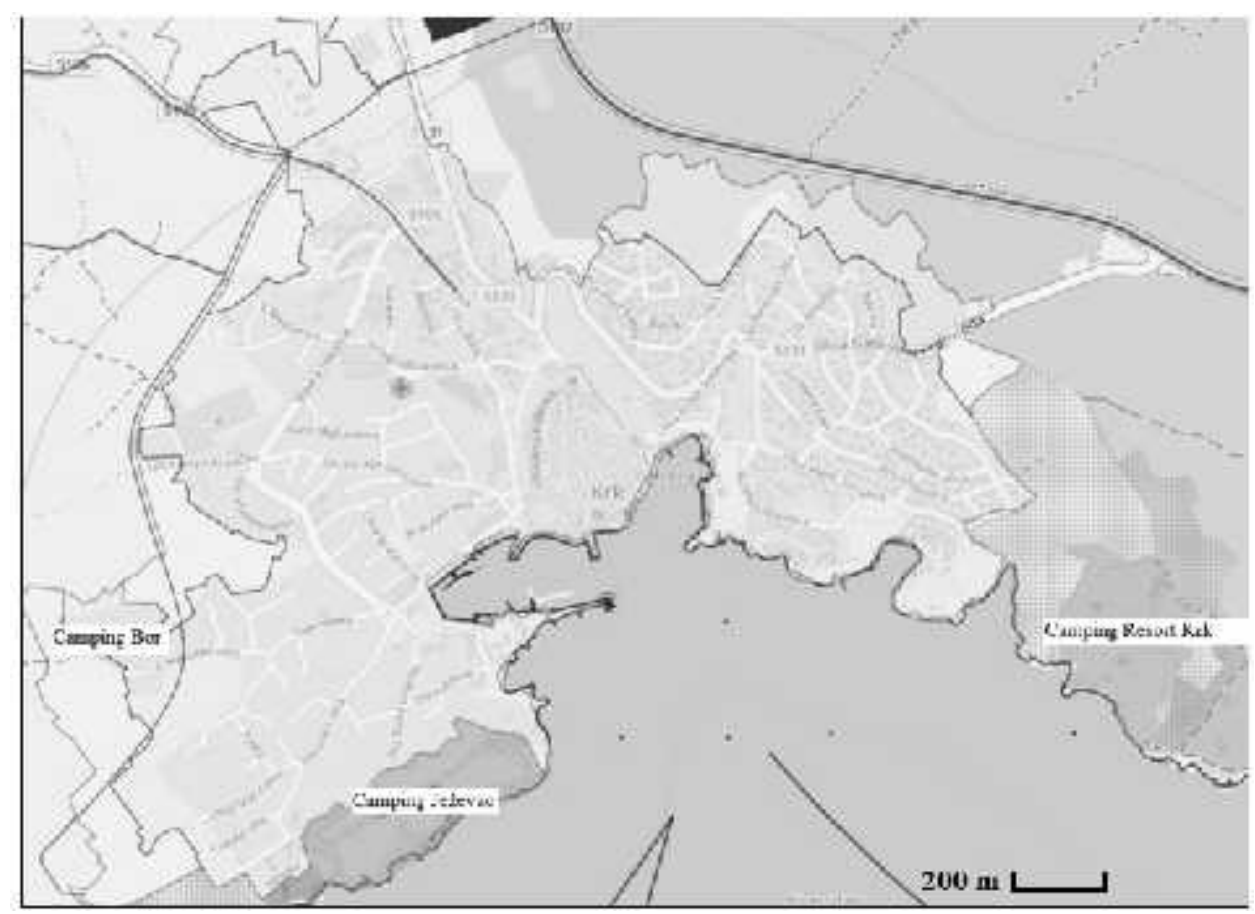

Fig. 4. Campsites in spatial structure of the town of Krk Source: Spatial Plan of the Town of Krk, 2007b

Because it is a campsite on private land, Camping Bor has not changed its surface since its foundation. Camping Ježevac spread in the period from 1984 to 1986 when it occupied its today's area. Although, according to the Spatial Plan of the Town of Krk (2007a), along the Camping Ježevac there is more area intended for tourism use, the campsite did not expand because of the unresolved property-legal relations.

Naturist Camping Politin did not enlarge its surface until 2013 when it became a conventional campsite, Camping Resort Krk. Then the changes of the surrounding area were made to provide new campsite pitches. A large number of mobile homes, as well as wellness center were built, sanitary facilities (toilets, showers etc.) were expanded, a forest next to the campsite was cut, the area was cleansed from rocks, the drywalls were removed from the shabby surrounding area and asphalted access roads and roads in new parts of the camp were built. All of these actions have led to increased environmental pressure than it was before. In order to compensate for negative environmental impacts, the camping itself has put more emphasis on ecology and sustainable tourism development. In 2014, a facility for biological wastewater treatment and ecological irrigation was established (Camping Adriatic, 2017). Maintenance of the environment is now one of the main tasks for camping management, and partly because of it, the camping became a family eco-camp with 5-star category in 2016, the first and the only campsite with the highest categorization in Croatia (Camping Adriatic, 2017). A new category was followed by the facilities in the camping supply. An aquapark was 
opened, new luxurious mobile homes and tents for glamping were set up, sanitary facilities were enlarged, a cinema amphitheater was made etc. Observing all the facilities of Camping Resort Krk it is obvious that the traditional way of camping in its supply no longer exists and that there has been a exclusive camping resort established. As a consequence, there is a stronger spatial impact identified in the Camping Resort Krk than in the case of the other two campsites in town. This leads to the conclusion that the increase of the tourism supply influences on the enlargement of the spatial and environmental impacts, usually in negative way. Camping Resort Krk, which once used to be one of many accommodation facilities in the town of Krk, has now become the camping tourism destination for itself, because the majority of camping tourists can find all they need and want for their vacation inside the campsite. Although Camping Resort Krk became a conventional camping, Tomaževo, the only naturist beach in town, is located right next to the campsite, so camping did not lose part of old guests who prefer naturism.

As camping tourists continue to link concept of camping closely with nature, it can be assumed that the tourism development in the town of Krk has had a negative influence on camping tourism, since the campings Bor and Ježevac practically merged with the built parts of the settlement. On the other hand, Camping Resort Krk is still surrounded by coniferous forests and macchia. In order to preserve the identity and main characteristic of camping tourism (stay in nature environment), in all campsites in the town of Krk at least $40 \%$ of their total surface have to be green and park areas (Spatial Plan of the Town of Krk, 2007a).

\section{QUESTIONNAIRE SURVEY IN THE CAMPSITES OF THE TOWN OF KRK}

\section{Camping Ježevac - example of traditional camping}

In Camping Ježevac, traditional way of camping can still be recognized. Although, German tourists are presented in highest percentage, the most important and influential guests in this campsite are Slovenians (who are often calling themselves, "pavšalisti" or seasonal guests - these guests are renting camping pitch for the whole season and that same pitch cannot be leased to other guests in the same time). Apart from Slovenians, it is possible to notice higher numbers of guests from Italy and Austria. Local guests Croatians - are more presented in this traditional way of camping, which is not a case in other campsite types. One the other hand, more demanding guests who are willing to pay more for the given service, i.e. from Belgium and Denmark are underrepresented. Dutch guests are also present, but not in such a high percentage as in exclusive and small family run campsites (Fig. 5). 


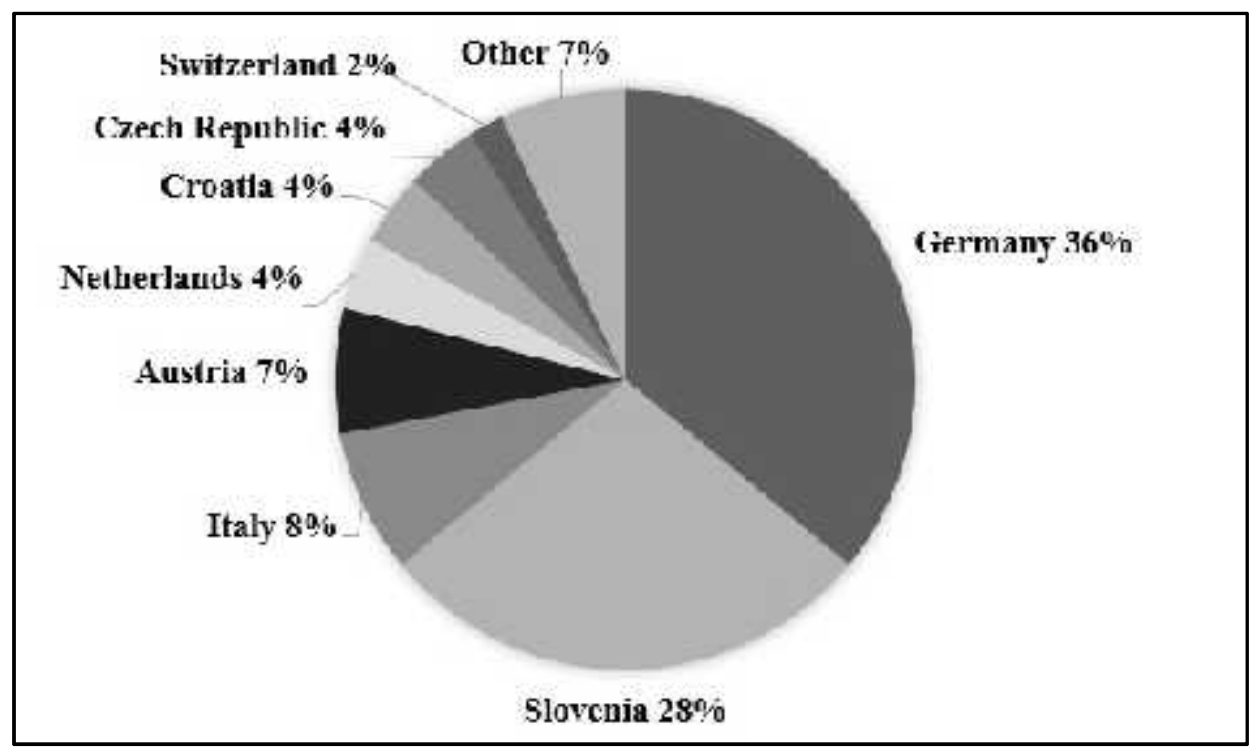

Fig. 5. Tourist nights by nationalities in Camping Ježevac in 2015 Source: Camping Ježevac Internal Statistics, 2015

In Camping Ježevac 62 guests were interviewed ( $30 \mathrm{M}$ and $32 \mathrm{~F}$ ). Excluding Croatians, almost $49 \%$ of foreign participants have already visited Camping Ježevac 10 or even more times. From this data it is easy to conclude that traditional camping tourists are very loyal guests who are coming quite a number of years in Ježevac (there is more than one case where several generations within same family have been spending holidays together).

Some of the most important characteristics of holidays in traditional campsite Ježevac were: "atmosphere as at home", socializing with family and friends, children safety and location within town of Krk. Although there is a wide tourism supply in this campsite: sports courts and fields, animation, restaurants etc., guests are quite unsatisfied with the quality of its facilities: beach, congestions, lack of children areas, sanitary facilities, lack of multilingual signs (lack of Slovenian language) etc.

In general, guests from Slovenia are the most unsatisfied camping tourists of Krk's campsites, but the vast majority of them are sure that they will come back again next year to Camping Ježevac. One of the major characteristic of traditional camping is loyalty. Guests who are coming year by year are attracted by the campsite facilities, and less by the tourism supply in town. It is possible to conclude that campsite is tourism microdestination by itself. To support this thesis, several guests noted: "It is unlikely that I can imagine at all spending my holiday in any other place rather than Ježevac!"

Because traditional campsites have their regular guests, most of them leave their camping equipment in the campsite all year round. Moreover, traditional camping 
tourists are proud of their camping lifestyle and they don't want to change it at all. They are used to spend time socializing with other guests (playing cards, cooking, partying etc.). This opinion is specially spread among older population and one of them said: "I don't need either swimming pool, nor waterpark, nor A/C in the trailer like those over there have (e.g. in Camping Resort Krk). As long as we have "our" people and fishermen festivities, we already have all".

\section{Camping Resort Krk - example of modern and exclusive camping}

Camping Resort Krk can be recognized as a role model for exclusive campsites. Because of wide spectrum of supply, many facilities, high service level, but also quite high price of camping, Camping Resort Krk follows all the trends of modern camping. National structure of the guests also follows the same pattern: most of the guests are coming from Germany, the Netherlands, Austria and Scandinavia (some of the European richest and most developed countries). As a result, national structure of the guests is completely different from the traditional campsite example - Camping Ježevac (Fig. 6).

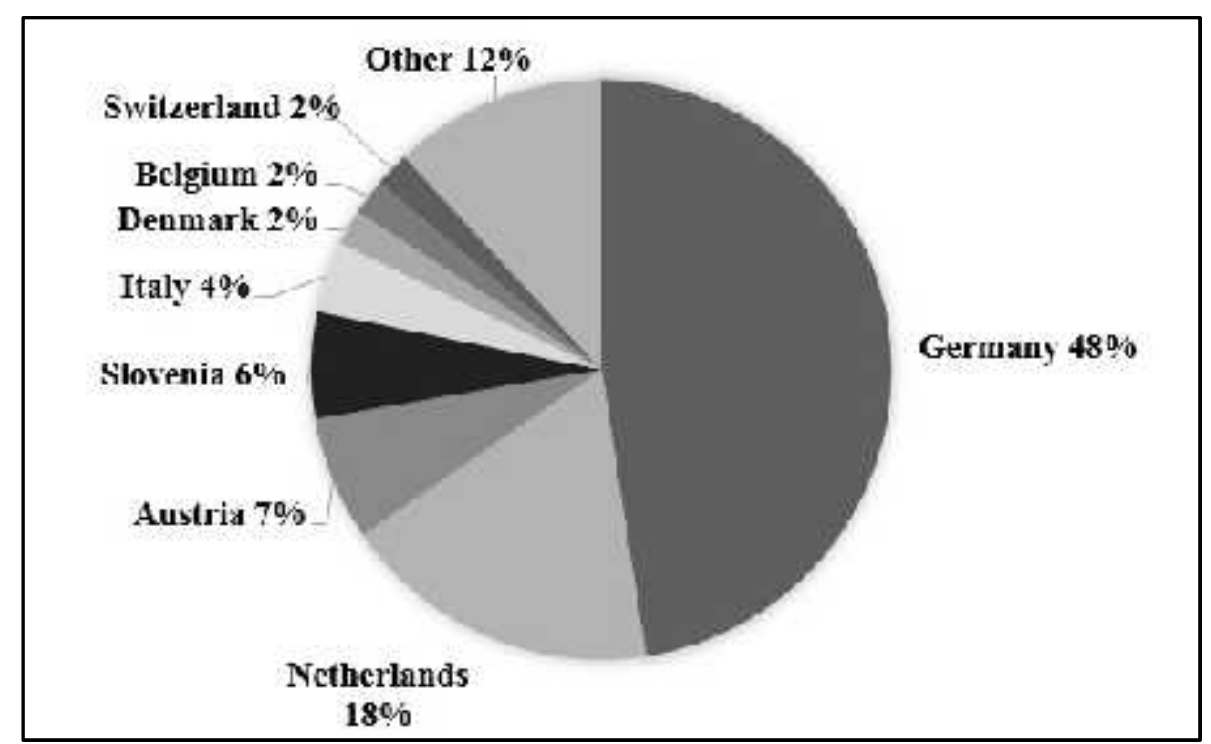

Fig. 6. Tourist nights by nationalities in Camping Resort Krk in 2015

Source: Camping Resort Krk Internal Statistics, 2015

Camping tourists are loyal to Croatia as a destination (79\% of them have already visited Croatia at least once). Due to the fact that Camping Resort Krk is a new campsite, it is hard to conclude on guests' loyalty, although there are several cases of those who have already been guests of this camping resort. Many of them (65\% of respondents) would like to come back to the Croatia, but returning to the exact same campsite was not so frequent answer as in traditional campsite (48\% of respondents in exclusive compared 
to $58 \%$ of them in traditional campsite). This type of camping tourists, i.e. modern camping tourists, could be more eager to explore as much as possible different places.

Guests of the Camping Resort Krk are paying a lot attention on the service and the facilities, similarly as guests in other exclusive campsites. On this example can be shown consistency in tourism: if you are paying more, you are expecting more to get for your money. More than any other campsite guests, guests in the exclusive campsites want to feel value for money, high level of service, good care and entertainment for their children, recreational options (such as rent-a-bike, swimming pools, massages etc). Camping Resort Krk guests are also showing satisfaction with the nature and surrounding area. Here can be also confirmed another thesis of modern camping tourism: socializing and making new connections is also important for modern camping tourists, but still, individuality should be respected, personal space is restricted (strictly separated pitches with the beds of flowers or bushes). Some of the Resort guests are not identifying this place like campsite but like 5-star hotel in the open space (mobile home village and glamping tent village).

Since Camping Resort Krk does not provide opportunity of leaving equipment in the Resort, many guests will store their equipment in the camping depots during the winter (again, higher income and standard is proved). Ownership structure is also an indicator of difference between the campsites: majority of guests are staying in the rented vehicles or in mobile homes and the tents rented by one of the agencies. Agencies do not even offer this service in other campsites due to the fact that mentioned service is too expensive for their guests.

\section{Camping Bor - example of small family run camping}

Comparing small, family run campsite (Camping Bor) with other types of campsites, it can be noticed that campsites of this type are transitional types of campsites. In Camping Bor traditional camping characteristics (such as importance of socializing, atmosphere) can be found, but they are combined with characteristics of modern and exclusive camping: wide supply of service and entertainment facilities. In small family run campsites, nationality structure of camping tourists is similar to Croatian camping tourism in general, but also, sometimes it is possible to find much more diverse nationality structure than in other campsite types (Fig. 7). 


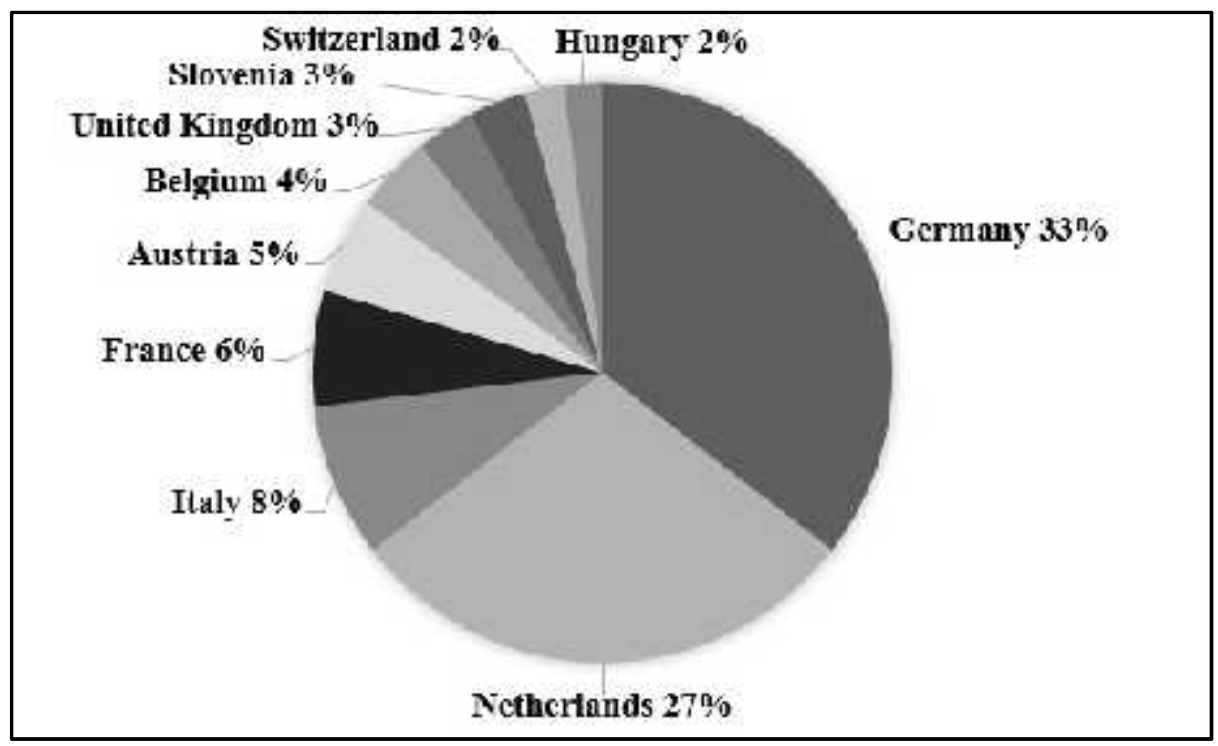

Fig. 7. Tourist nights by nationalities in Camping Bor in 2015

Source: Camping Bor Internal Statistics, 2015

Similar to other two types of campsites, campsite guests in small family run campsite are showing loyalty to the Croatia as a destination, but not to the island of Krk and Camping Bor. More than two third of the questioned guests stated that they are for the first time in this destination (campsite and an island) and it is quite likely that this guests won't come back next year to the same place. Six of them, all from the Netherlands, gave the same answer: "Every year we are choosing new destination at the Adriatic in Croatia." Higher level of loyalty is noticed among German and Slovenian guests (60\% of German and $75 \%$ Slovenian respondents have visited this campsite and they are planning to visit it also next year). Majority of the respondents (69.44\%) in this campsite was attracted by recommendation in tourist guide (for example in Dutch ANWB or German ADAC). One of the differences between traditional and exclusive campsites on the one side and small privately and family run campsites on the other side is the fact that for the guests in small family run campsites surrounding area (the town of Krk or the island of Krk) has bigger importance as a tourism destination than the campsite by itself.

These camping tourists are not such demanding guests, as for example in exclusive campsites, but value for money and given-taken balance is very important for them. Guests in this type of campsite also tend to visit more destinations during their holidays (several campsites during their trip) and also it is logical to conclude that their average stay is much shorter than in other two types of campsites. Although it is possible to store the equipment in the campsite during the winter, only small number of guests does so because of already mentioned fact that it is not likely that many guests will come next year to the same destination. 
Most of the equipment is privately owned (similar to the traditional camping) and type of the camping can be connected with the age groups: older campers are tending to have motorvans and trailers (bigger comfort but also higher income groups), while younger guests are coming more often with the tents. Unique feature in this small family run campsite is significant proportion of guests $(22.2 \%)$ who are going on the holiday with their motorcycles. Guests on the motorcycles are also one of the most mobile guests who stay shorter in one campsite, but tend to visit more campsites during their holidays.

\section{Differences in attitudes and habits of respondents in the campsites of the town of Krk}

Although spatial distance between campsites in the town of Krk is not wide, characteristics, but also attitudes and habits of the guests are significantly different (Tab. 2). Differences can be noticed through habits of camping: for example, guests in traditional campsites are choosing camping as their lifestyle during holidays and transfer this to their children, while for guests in exclusive campsites, camping is not the only type of spending holidays.

Differences are noticed in the way of storing equipment (in campsite for traditional guests and at home or in camping depot for guests of exclusive campsites and small family run campsites). Storing their equipment in camp-depots is more likely for the guests from exclusive campsites due to the price of depo and their higher income. Guests of traditional and small family run campsites are most often owners of their equipment (usually older and lower quality than the equipment of the guests from the exclusive campsites). Within exclusive campsite guests, due to their higher income, it is noticed that they more often than guests from other campsite types rent or borrow camping equipment. While analyzing importance of camping supply elements and guest satisfaction, it can be concluded that between some elements there are not significant differences (for example categories: "nature" and "safety"). In some other elements of supply there are differences connected with the campsite price range but also with the expectation of the guests. It is logically to expect that guests who are paying more for their holidays expect more and value for money will be quite important. Guests in exclusive camping are the most demanding ones and for them additional facilities, animation, entertainment, cleanness, gastronomy etc. are very important. It can be observed that for these guests, supply and possibilities in the campsite (resort) are more important than the tourism destination where the campsite is located. Completely opposite situation is in traditional campsites. For traditional campsite guests location of campsite within destination is very important. This importance can be seen through their main habits: walking, entertainment/clubbing, shopping etc. Although, same elements are having importance in other types of campsites, the most important elements to the guests of small family run campsites are: price (these are guests with the lowest income) and the distance between destination and their home. Also, for this 
types of guests is important that roads and connections between home and destinations are good because it is noticed that guests who are preferring to stay in small family run campsites during their holiday are often combining stay in several different campsites.

Tab. 2. Results of questionnaire among the guests of campsites in the town of Krk

\begin{tabular}{|c|c|c|c|c|c|c|}
\hline & $\begin{array}{r}\text { BOR } \\
\text { (small fami } \\
\text { campin } \\
(\mathbf{N}=36\end{array}$ & & $\begin{array}{r}\text { JEŽEV } \\
\text { (traditional c } \\
(\mathrm{N}=62\end{array}$ & ing) & $\begin{array}{r}\text { CAMPING } \\
\text { KRK } \\
\text { (exclusive ca } \\
(\mathrm{N}=29\end{array}$ & ORT \\
\hline \multirow{5}{*}{$\begin{array}{l}\text { How often do } \\
\text { you go } \\
\text { camping? }\end{array}$} & First time & 4 & First time & 3 & First time & 4 \\
\hline & $1-4$ times & 6 & $1-4$ times & 16 & $1-4$ times & 7 \\
\hline & $5-9$ times & 12 & $5-9$ times & 12 & $5-9$ times & 9 \\
\hline & $10-14$ times & 3 & $10-14$ times & 6 & $10-14$ times & 6 \\
\hline & $\geq 15$ times & 11 & $\geq 15$ times & 24 & $\geq 15$ times & 3 \\
\hline \multirow{4}{*}{$\begin{array}{l}\text { Camping } \\
\text { equipment }\end{array}$} & Tent & 11 & Tent & 11 & Tent & 8 \\
\hline & Trailer & 15 & Trailer & 30 & Trailer & 12 \\
\hline & $\begin{array}{l}\text { Recreational } \\
\text { vehicle }\end{array}$ & 10 & $\begin{array}{l}\text { Recreational } \\
\text { vehicle }\end{array}$ & 13 & $\begin{array}{l}\text { Recreational } \\
\text { vehicle }\end{array}$ & 3 \\
\hline & Mobile home & 0 & Mobile home & 8 & Mobile home & 6 \\
\hline \multirow{3}{*}{$\begin{array}{l}\text { Property of } \\
\text { equipment }\end{array}$} & Private & 34 & Private & 49 & Private & 19 \\
\hline & Rented & 2 & Rented & 9 & Rented & 10 \\
\hline & Borrowed & 0 & Borrowed & 4 & Borrowed & 0 \\
\hline \multirow{3}{*}{$\begin{array}{l}\text { Equipment } \\
\text { location in the } \\
\text { off-season }\end{array}$} & $\begin{array}{l}\text { In camping } \\
\text { depot }\end{array}$ & 5 & $\begin{array}{l}\text { In camping } \\
\text { depot }\end{array}$ & 4 & $\begin{array}{l}\text { In camping } \\
\text { depot }\end{array}$ & 10 \\
\hline & At home & 29 & At home & 19 & At home & 16 \\
\hline & $\begin{array}{l}\text { At the } \\
\text { campsite }\end{array}$ & 2 & $\begin{array}{l}\text { At the } \\
\text { campsite }\end{array}$ & 38 & $\begin{array}{l}\text { At the } \\
\text { campsite }\end{array}$ & 3 \\
\hline \multirow{11}{*}{$\begin{array}{l}\text { Level of } \\
\text { satisfaction } \\
\text { with the } \\
\text { attractions } \\
\text { and facilities } \\
\text { in camping } \\
\text { (1=lowest; } \\
5=\text { highest) }\end{array}$} & Nature & 4.25 & Nature & 4.26 & Nature & 4.34 \\
\hline & Safety & 4.53 & Safety & 4.38 & Safety & 4.58 \\
\hline & $\begin{array}{l}\text { Distance } \\
\text { from home }\end{array}$ & 3.92 & $\begin{array}{l}\text { Distance from } \\
\text { home }\end{array}$ & 3.91 & $\begin{array}{l}\text { Distance from } \\
\text { home }\end{array}$ & 3.72 \\
\hline & $\begin{array}{l}\text { Location } \\
\text { within } \\
\text { town of Krk }\end{array}$ & 3.81 & $\begin{array}{l}\text { Location } \\
\text { within } \\
\text { town of Krk }\end{array}$ & 4.88 & $\begin{array}{l}\text { Location } \\
\text { within } \\
\text { town of Krk }\end{array}$ & 4.20 \\
\hline & Gastronomy & 3.88 & Gastronomy & 3.88 & Gastronomy & 4.17 \\
\hline & $\begin{array}{l}\text { Roads and } \\
\text { the traffic }\end{array}$ & 3.97 & $\begin{array}{l}\text { Roads and the } \\
\text { traffic }\end{array}$ & 3.79 & $\begin{array}{l}\text { Roads and the } \\
\text { traffic }\end{array}$ & 3.89 \\
\hline & Prices & 4.17 & Prices & 3.37 & Prices & 3.48 \\
\hline & $\begin{array}{l}\text { Service, } \\
\text { entertainment }\end{array}$ & 3.39 & $\begin{array}{l}\text { Service, } \\
\text { entertainment }\end{array}$ & 4.02 & $\begin{array}{l}\text { Service, } \\
\text { entertainment }\end{array}$ & 4.55 \\
\hline & Cleanliness & 4.31 & Cleanliness & 4.36 & Cleanliness & 4.72 \\
\hline & Beach & 3.64 & Beach & 3.88 & Beach & 4.62 \\
\hline & $\begin{array}{l}\text { Value for } \\
\text { money }\end{array}$ & 4.08 & $\begin{array}{l}\text { Value for } \\
\text { money }\end{array}$ & 3.74 & $\begin{array}{l}\text { Value for } \\
\text { money }\end{array}$ & 4.00 \\
\hline
\end{tabular}




\section{CONCLUSION}

Based on differences in the capacity of campsites, location factors, spatial impacts and the consequences, characteristics of supply in campsites as well as motivations, attitudes and habits of camping tourists three types of campsites can be identified: a) traditional camping, b) exclusive camping, and c) small family run camping.

Traditional campsites are often located at the former edges of residential areas of cities and towns, which, due to the intensified primary and secondary housing, as well as building of tourism capacities, have come close to the camping or simply surround it. In traditional campings classic (or "old-fashioned") camping supply prevails. The majority of guests stay in tents, trailers or caravans, but nowadays supply in traditional campsites has been upgraded with mobile homes as accommodation capacities. Although the spatial impacts are smaller than in exclusive campsites, due to building of mobile homes they are becoming more and more intense. Traditional campsites attract a part of their old, loyal guests whose primary motivation during the stay is socializing, friendly atmosphere and staying in a familiar environment. For those camping tourists the primary tourism destination is the chosen campsite and the town or city in which the campsite is situated has the secondary importance. Guests of the traditional campsites combine their stay in the camping with visits to the town or city where the campsite is located for shopping and entertainment, but most of the time they spend in the campsite or at the nearby beach (traditional "Sun and Sea" concept of vacation).

Exclusive campsites have been appearing in Croatian tourism supply over the last fifteen years. They are emerging on new, remote locations from the local settlements or by modernization of former traditional campsites. Richer and more luxurious accommodation (mobile homes, tents for glamping) and other facilities are the main reasons for the more built areas than in traditional campings, although the environment is striving to be improved with well-maintained greenery. Due to the large supply of facilities, high quality and services, these campsites look like "outdoor hotels" in which guests still have a sense of staying in nature, but in a more luxurious way than in a traditional campsites. Large areas of this type of campsites are occupied by mobile homes as well as tents for glamping as a new camping supply. For guests in exclusive campings, camping supply (wide choice of catering, entertainment and wellness facilities) is the main reason for choosing a tourism destination. For that reason exclusive campsites could be recognized as a self-contained tourism destinations and for their guests tourism supply of surrounding towns and cities have less importance in choosing the holiday destination, so they do not leave the chosen campsite very often during the stay. It is important to note that the spatial and environmental impacts of these campsites are much stronger than in traditional campsites. Parallel with the rise of the camping category impacts (mostly negative) on the surrounding area are increasing. 
Small family run campsites stand out for the smaller area and the ambiance they offer. The basis of their attractiveness is a more quiet, family atmosphere, with quality, but no such diverse supply as in exclusive campsites. In this way, they follow the new concepts in camping industry. Although there are less built accommodation facilities (i.e. mobile homes, tents for glamping), due to the exclusive, more private atmosphere this type of campsite could also attract camping tourists of higher income. Guests of small family run campsites often visit a town or city where the camp is located, as well as the surrounding areas, and during vacation often combine stays in campsites in several different destinations.

In line with the qualitative transformation of camping tourism in the world, in the further development of camping supply in Croatia, an increase of the number of exclusive and small family run campsites can be expected, together with the decrease of the number of traditional campsites, part of which will surely be transformed into exclusive campsites. In general, this trend should also result with an increase of the category of Croatian campsites, as well as ecological standards and the specialization of campings towards to certain market segments of camping tourists. Thus camping tourism would remain an important place in the Croatian tourism structure.

\section{ACKNOWLEDGEMENT}

This research was conducted within the short-term financial support of the University of Zagreb for 2017 "Spatial implications of tourism and second homes' mobilities in local communities in Croatia".

\section{REFERENCES}

1.Camping Adriatic (2017). https://www.camping-adriatic.com/camping-krk-politin, (October 20 ${ }^{\text {th }}$ 2017)

2. Camping Bor Internal Statistics (2015)

3. Camping Ježevac Internal Statistics (2015)

4. Camping Resort Krk Internal Statistics (2015)

5. Croatian Bureau of Statistics (2014). Tourism in 2013. Zagreb.

6. Croatian Bureau of Statistics (2017). Tourism in 2016. Zagreb.

7. Cvelić-Bonifačić, J. (2003). Management kamping usluge u Hrvatskoj. Magistarski rad. Fakultet za menadžment u turizmu i ugostiteljstvu Sveučilišta u Rijeci, Opatija.

8. Hendija, Z. (2006). Kamping turizam. In: Hrvatski turizam: plavo, bijelo, zeleno (eds. Čorak, S, Mikačić, V.). Institut za turizam, Zagreb, 65-91.

9. Independent Internet Site of the Island of Krk (2015). otok-krk.org, (December $4^{\text {th }}$ 2015)

10. Seleši, M. (2010). Geografski aspekt kamping turizma u Istarskoj županiji. Magistarski rad. Prirodoslovno-matematički fakultet Sveučilišta u Zagrebu, Geografski odsjek. Zagreb. 
11. Smolčić Jurdana, D., Milohnić, I., Cvelić-Bonifačić, J. (2009). The features of naturist camping market. Tourism and hospitality management, 15 (2), 177-192.

12. Sladoljev, J. (1998). Kamping turizam: sve o kampingu - priručnik za vlasnike $i$ voditelje kampova. C.A.S.H, Pula.

13. Sladoljev, J. (2001). Naturistički kampovi i naselja: povijest, koncepcija i razvoj. C.A.S.H., Pula.

14. Sladoljev, J. (2008). Povijest jedne profesije: kampiranje i naturizam u Hrvatskojfakti i kronologija, Top camping pool, Poreč.

15.Spatial Plan of the Town of Krk (2007a).

http://www.sn.pgz.hr/default.asp?Link=odluke\&id=11997, (October $20^{\text {th }} 2017$ )

16. Spatial Plan of the Town of Krk (2007b). krk-ppu.gis.com.hr, (October 20 ${ }^{\text {th }} 2017$ )

17. State Geodetic Administration (2005). Central registry of spatial units in the Republic of Croatia. Zagreb.

18. Town of Krk Tourist Board (2017).

http://www.tz-krk.hr/en/where-to-stay/249-auto-camps, (October 20 ${ }^{\text {th }} 2017$ )

19. Zlatni otok hotelijerstvo, turizam, trgovina (2017),

http://zse.hr/userdocsimages/prospekti/Prospekt-ZLTO.pdf, (October $20^{\text {th }} 2017$ ) 